\title{
New Concept of Digital Structuring Landscape of the Island Systems of the Vladivostok City District
}

\author{
Valeriy Titovich Starozhilov \\ Pacific International Landscape Center, Far East Federal University, Vladivostok, Russia \\ Email: starozhilov.vt@dvfu.ru
}

How to cite this paper: Starozhilov, V. T. (2019). New Concept of Digital Structuring Landscape of the Island Systems of the Vladivostok City District. Journal of Geoscience and Environment Protection, 7, 114121.

https://doi.org/10.4236/gep.2019.72008

Received: January 21, 2019

Accepted: February 22, 2019

Published: February 25, 2019

Copyright $\odot 2019$ by author(s) and Scientific Research Publishing Inc. This work is licensed under the Creative Commons Attribution International License (CC BY 4.0).

http://creativecommons.org/licenses/by/4.0/

\section{c) (i) Open Access}

\begin{abstract}
A new concept of digital vector-layer structuring of landscape space at the local level (on a scale of 1:25,000) is considered on the example of Russian island and adjacent island systems of the Vladivostok urban district. Synthesis, analysis and evaluation of the internal and external content of landscape systems are carried out and altitude complexes of tracts are identified, in each of which altitudes are distinguished. It is noted that one of the main criteria for identifying high-altitude complexes and levels is the high-altitude criterion and the quantitative and qualitative changes in their internal content, taking into account the state of erosion-denudation lowland and mountain landscape systems formed under the influence of the Earth's real material-energy flows and first of all gravitational energy. According to these criteria, landscape areas are classified and vertex, saddle, upper slope, middle slope and other altitude complexes of tracts are distinguished in each of which altitude levels are distinguished. Structuring and classification proposed to the reader are presented for further study of structures as objects of industry-specific indication and possibilities of using high-landscape complexes as development areas. Noted, as well as the fact that the study was conducted for the first time and is aimed at the practical implementation of the landscape approach in the development of landscape systems, defines the relevance of the work performed.
\end{abstract}

\section{Keywords}

Concept, Digital, Structuring, Landscape, Tract, Complex, Level, Relief, Development

\section{Introduction}

The article proposed to the reader is a continuation of the presentation of the 
results of the research of the Far East Federal University Pacific International Landscape Center on the strategic program study of the Pacific landscape belt of Russia. In this article for the first time proposes a new concept of digital vector-layer structuring of landscape space at the local level (on a scale of 1:25,000) using the example of Russian island and adjacent island systems of the Vladivostok urban district. Previously, this could not be done. This is due to the fact that there was no published in the open press morphological digital vector-layer map of the tracts and groups of tracts of the territory under consideration. In 2018 at the Far East Federal University Pacific International Landscape Center under the guidance of Professor V.T. Starozhilova such a morphological map (that is, a digital map of the geographical structure) was compiled and published (Starozhilov, Oznobikhin, Dedeva, \& Kudryavtsev, 2018). With the advent of such a cartographic basis, aimed at the practical implementation of the landscape approach during development, it became possible to carry out a synthesis, analysis and assessment of the internal and external content of landscape systems and to identify high-altitude complexes of tracts, each of which has highaltitude levels. The classification is based on the synthesis, analysis and evaluation of the lithological-geomorphological structure, the fundamentals of landscape, taking into account the landscape-forming orographic, climatic and phytostating factors, marginal continental dichotomy, the nature of the development of erosion-denudation and other geosystems. One of the main criteria for identifying high-altitude complexes and levels is the high-altitude criterion and the quantitative and qualitative changes in their internal content, taking into account the state of erosion-denudation lowland and mountain landscape systems formed under the influence of the Earth's material-energy flows and first of all gravitational energy. According to these criteria, landscape areas are classified and vertex, saddle, upper slope, middle slope and other altitude complexes of tracts are distinguished in each of which altitude levels are distinguished. Structuring and classification proposed to the reader are presented for further study of structures as objects of industry-specific indication and possibilities of using high-landscape complexes as development areas. Noted, as well as the fact, the study was conducted for the first time and is aimed at the practical implementation of the landscape approach in the development of landscape systems, determines the relevance of the work performed.

\section{Materials and Methods}

Considered unpublished materials of the results of field scientific and practical geological, geographical and geographical long-term research about. Russian (as an object of Southern Primorye, materials are in the funds of "Primgeolkom"). The work is based, first of all, on the author's results obtained when conducting special predictive geological and geographical assessments of the prospects for the 1980s about. In Russian island of location quartz-feldspar raw materials for the production of porcelain, as well as prospects for the discovery of phosphate 
rock. State tasks, works were performed using not only geological, but also geographic integrated methods. As a result, field materials were obtained on geology, geomorphology, vegetation, moisture, water exchange, erosion-denudation systems, and other components of the internal contents of landscapes. In addition to these materials, materials from field work performed in 2014 (Starozhilov \& Oznobikhin, 2015), as well as the results of route profiling and interpretation of satellite images made by the author and graduate students of the second year of study Kudryavtsev A.A. and Deleva A.A. Materials of correlations and interrelationships of rather significant data samples were studied not only on relief, vegetation and soils, but also on bedrock and loose rocks, climate. Also, the power of loose accumulations, transit of detrital material, moisture, depth of cut, thickness of dismemberment, intensity of physical and chemical weathering, meso and microclimatic features were analyzed. First of all: solar radiation and radiance, temperature, wind, humidity, precipitation, snow cover, depth of freezing, various natural and extreme phenomena. In addition, based on the presentation of the significance of all components and factors of the landscape, including the foundation as a material component and a factor of its dynamics, we studied the high-altitude complexes of the tracts as a fundamental and loose foundation.

The materials of perennial (more than 30 field seasons) geological and geographical studies of the nature of the Pacific landscape belt of Russia were also used (Figure 1).

As the cartographic basis, the author's Landscape Map of the tracts and tracts of the tracts was used. Russian and adjacent islands of the Vladivostok urban district in the scale of 1:25,000 (Starozhilov, Oznobikhin, Dedeva, \& Kudryavtsev, 2018).

In the study applied methods: the method of conjugate analysis of intercomponent and interlandscape connections of landscape components (basement, relief, climate, water, vegetation, soil); the method of typological mapping in the classification system developed by us: tract, terrain, species, genus, subclass, landscape class; the concept (methodology) of the vector stratified landscape zoning and the study of the hierarchical structure and internal geographic content of the taxons of such zoning within the framework of mountain landscape science.

\section{Results}

In general, based on the analysis, synthesis and evaluation of significant field and theoretical material, the fundamental result of these studies has been established, namely, to implement the concept of structuring high-rise landscape structures as natural bases for conducting areas harmonized with nature, the development of sectoral areas should be primarily digitized Layered morphological landscape basis (for example, Russky Island is a vector-layered local morphological landscape map of Russian Island.), which at the digital level gives knowledge of the 


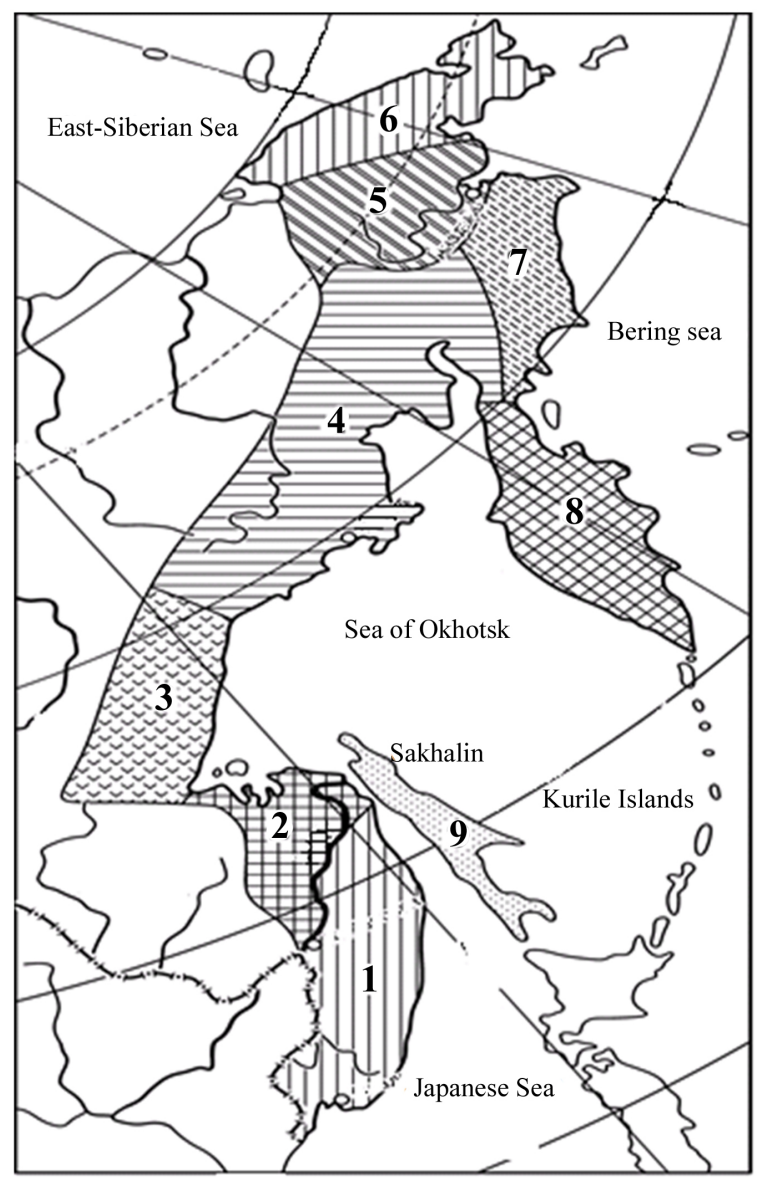

Figure 1. Pacific landscape belt of Russia. Belt areas: 1. Sikhote-Alinskaya, 2. LowAmurskaya, 3. Priokhotskaya, 4. Kolymskaya, 5. Anadyrskaya, 6. Chukotskaya, 7. Koryakskaya, 8. Kamchatskaya, 9. Sakhalinskaya.

structure of the geographical space involved in the development of landscape structures. Such results make it possible to analyze the areas being mastered by digitized landscapes.

As a result of research tracts on. Using a vector-layered digital landscape map, Russian island has established that in structures according to altitude criterion, slope angles and internal landscape content (taking into account the state of erosion-denudation lowland and mountain landscape systems formed under the influence of the real energy flows of the Earth and first of all gravitational energy) on the example of. Russian stand out high-altitude complexes tracts. They are different and the upper slope, middle slope and other altitude complexes of the tracts are distinguished, each of which, in turn, distinguishes the elevation levels (Table 1, Figure 2). Below, for example, only some of them are described, it is simply impossible to describe everything in this work.

Upper slope altitude complexes of stows are slope-like stows, the height is occupied by the upper third of the slope and characterized by slopes of surfaces from 3 - 5 to 45 degrees or more. They have low moisture content, slowed down, in terms of the development of gravity processes, the dynamics of erosion-denudation 


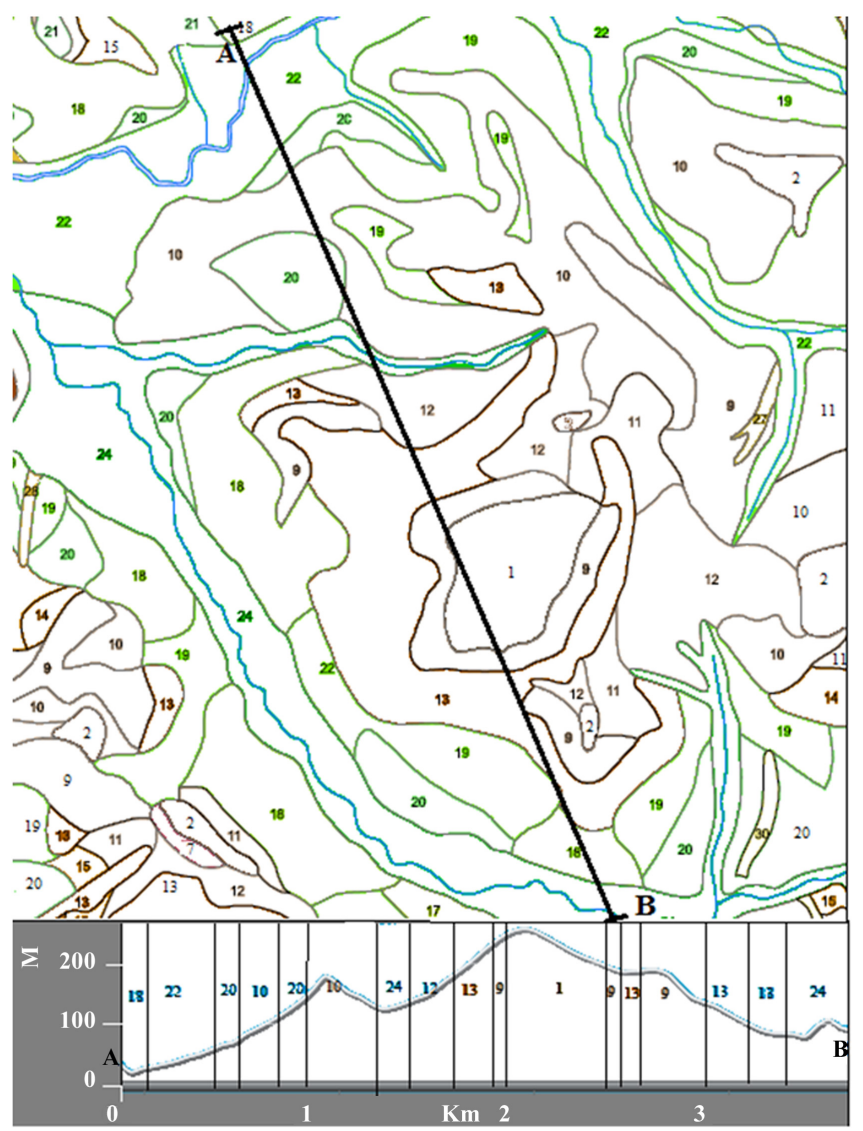

Figure 2. Map and profile of high-altitude complexes of tracts and their levels (fragment). High-altitude complexes of tracts and their levels: (tie numbers on the map fragment and the profile correspond to the figures on the map of the tracts of Russian island) (Starozhilov et al., 2018): Vertex: 1. Vertex high 2. Vertex medium-high with xerophytic forests on brown forest eroded soils. Saddle: 7. Saddle of uneven elevations. Upper-slope: 9. Upper-slope steep xerophytic oak trees on brown forest primitive soils 10. Upper slope steep with mesophytic oak forests on brown forest low-power soils 11. Upper slope medium steep with oak forests on medium brown forest soils 12. Upper-middle powerful gentle slope under mesophyticoak forests on brown forest soils of the low-power. Mid-slope: 13. Mid-slope with oak forests on brown forest soils eroded 14. Mid-slope with xerophytic oak forests on sod-brown forest soils eroded 15 Mid-slope with mesophytic oak forests on sod-hrown forest poorly eroded soils. Lower slope: 13. Low-slope precipitous xerophytes from oak forests on brown low power sails 18. Low-slope with shrub-grassy oak forests on brown forest thin soils 19. Low-slope middlecoiled with fern oak trees on sod-brown forest low power soils 20. Low-slope and flat slopes with light forests and meadows on brown forest soils 21 . Medium and high boggy with deciduous forests on brown forest bleached soils Low Terraces: 22. Low terraces with deciduous forests in combination with meadows on sod gleyovatsoils Ovrazno-balochniy complex: 27. Shirokopadevye permanent watercourses 28 . Uzkoraspadkovye permanent watercourses.

processes. They are divided into high-altitude levels of the tracts: gently sloping with slopes 3 - 5 with mesophytic oak forests of mongolian oak with ash nasolithicforbred and lespedetsevy on brown forest powerful loamy-stony soils; srednekrutye with slopes of 20 - 30 with oak forests with fern on brown forest medium-thick loamy-stony soils; steep with slopes of 20 - 45 with mesophytic 
Table 1. Fragment of the classification of high-altitude complexes and levels of tracts Russian island and adjacent islands of the Vladivostok urban district.

\begin{tabular}{|c|c|c|}
\hline $\begin{array}{l}\text { High-rise } \\
\text { systems } \\
\text { tracts }\end{array}$ & Height levels of tracts & $\begin{array}{l}\text { Slope } \\
\text { angle }\end{array}$ \\
\hline \multirow{5}{*}{ 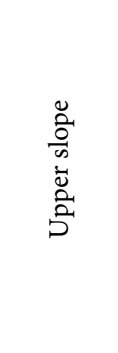 } & steep with shrub xerophytic oak forests and their overgrown thickets on & more \\
\hline & brown forest primitive low-power highly stony eroded soils & $45^{\circ}$ \\
\hline & $\begin{array}{l}\text { steep with mesophyticoakwoods from mongolian oak with ash } \\
\text { nosolithicforbred-lezpedetsevye on brown forest thin loamy-stony soils }\end{array}$ & $20^{\circ}-45^{\circ}$ \\
\hline & $\begin{array}{l}\text { middle-spruce with fern oak forests on brown forest medium-thick } \\
\text { loamy-stony soils }\end{array}$ & $20^{\circ}-30^{\circ}$ \\
\hline & $\begin{array}{l}\text { gentle with mesophyticoakwoods from mongolian oak with ash } \\
\text { nosolithicforbred-lesepets on brown, thick forest loamy-stony soils }\end{array}$ & $3^{\circ}-5^{\circ}$ \\
\hline \multirow{5}{*}{ 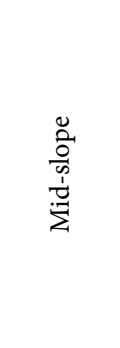 } & steep with xerophyticlespecid oak forests on brown forest thin stony eroded & More \\
\hline & loamy-stony soils & $45^{\circ}$ \\
\hline & $\begin{array}{l}\text { steep with xerophytic grassy oak forests on brown forest typical thin and } \\
\text { soddy brown loamy-stony eroded soils }\end{array}$ & $20-45^{\circ}$ \\
\hline & $\begin{array}{l}\text { srednekrutye with mesophytic oak forests, their light forests on soddy brown } \\
\text { thin loamy-stony poorly eroded soils }\end{array}$ & $20^{\circ}-30^{\circ}$ \\
\hline & $\begin{array}{l}\text { gently sloping with mesophytic oak forests, their light forests on sod-brown } \\
\text { medium-thick loamy-stony soils }\end{array}$ & $3^{\circ}-5^{\circ}$ \\
\hline \multirow{4}{*}{ 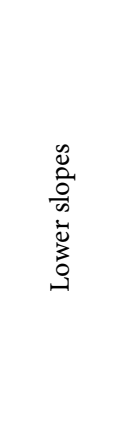 } & $\begin{array}{l}\text { steep with xerophytic oak forests and grassy meadows on brown forest thin } \\
\text { and fragmented soils }\end{array}$ & $\begin{array}{c}\text { More } \\
45^{\circ}\end{array}$ \\
\hline & $\begin{array}{l}\text { steep with xerophytic shrub-grassy oak forests on brown forest thin stony } \\
\text { eroded soils }\end{array}$ & $20^{\circ}-45^{\circ}$ \\
\hline & $\begin{array}{l}\text { middle-sprouted with fern oak forests of mongolian oak with japanese alder, } \\
\text { maples and lindens, forbs and grass meadows on brown forest typical and } \\
\text { sod-brown gleypowerful and medium-sized loamy-gravelly soils }\end{array}$ & $20^{\circ}-30^{\circ}$ \\
\hline & $\begin{array}{l}\text { gentle slopes and plumes with light forests and forests of alder Japanese forbs } \\
\text { and shrubs combined with forb, forb-sedge and sedge-reed meadows on } \\
\text { brown forest gley heavy loamy stony soils }\end{array}$ & $3^{\circ}-5^{\circ}$ \\
\hline
\end{tabular}

oak forests of mongolian oak with ash nosolithicforbred and lespedets on brown, forest thin, loamy-stony soils; steep with slopes over 45 with xerophytic shrub oak trees and their overgrown thickets on brown forest primitive low-power highly stony eroded soils.

It is important to note that the differences in the high-altitude complexes of the tracts are reflected in the boundaries of the tracts of the groups highlighted on the morphological map, and the differences in the elevation levels within the high-altitude complexes coincide with the boundaries of the corresponding tracts on the map. Such a cartographic coincidence of boundaries will in many respects help to further carry out the sectoral indication and practical implementation of the landscape approach to solving the problems of land development.

As an example of the necessity and usefulness of the analysis and evaluation of materials on high-altitude complexes and levels of stows, we present some possibilities for applying the proposed new structuring of landscape space in the construction industry. Already at the design stage, such materials will help designers in assessing the landscape space for urban purposes, for example, when choosing 
construction sites. From the internal content (height, angle of inclination, the dynamics of the erosion-denudation system, the development of physiographic processes, etc.) of the high-altitude complexes of the tracts depends largely on the appropriateness of their choice. When choosing construction sites, first of all, they pay attention to their sizes, slopes of surfaces, development of physiographic processes and dissection. Construction use of sites is limited to active landslide and subsidence processes. They require special attention, because quite often, after the construction of a building, these processes become very intense due to the additional load and violation of the groundwater regime.

Significant deviations from the planning norms and the neglect of natural conditions cause the natural dismemberment of the construction site, and this leads to the appearance of negative consequences of construction.

\section{Conclusion}

The proposed structuring and classification of landscapes are important not only from the point of view of the development of the scientific foundations of landscape science, but also as a direction of research on the strategic possibilities of its use in the integrated and sectoral development of landscape space. The concept of high-altitude complexes of tracts and their high-altitude levels proposed to the reader is considered as a promising direction of landscape geography in carrying out practical tasks in the development of territories. Subject to the use of vector-layer mapping, the study of tracts using component, morphological, areal, multi-scale vector-layer display (Starozhilov et al., 2009b, 2009c, 2009d, 2012; Starozhilov, 2017) will allow cartographically using modern digital computer technologies to proceed to the consideration of scientific and practical planning tools harmonized with nature forecasting of economic, social, ecological and other geosystems. Structuring will be conducive to solving the problems of optimizing the natural environment of the regions. At present, the Far East Federal University Pacific International Landscape Center continues to develop a conceptual methodology for digitizing structuring the practical implementation of the method and the possibility of using these materials in practice. The geographers of Far East Federal University have already prepared a basic landscape map of Primorsky Krai at a scale of 1:500,000, a landscape map of the Russian island at a scale of 1:25,000, a landscape classification of the Sakhalin region (Starozhilov, 2004, 2011, 2016, 2018; Starozhilov \& Zonov 2009a), continue research in other regions of the Pacific landscape belt of Russia.

\section{Fund}

The studies were carried out with the financial support of the Russian Foundation for Basic Research (Project-18-05-00086-A).

\section{Conflicts of Interest}

The authors declare no conflicts of interest regarding the publication of this paper. 


\section{References}

Starozhilov, V. T. (2004). Geodynamic Evolution of Transition Zones of Northeast Asia to the Pacific Plate. Hydrometeorological and Geographical Research in the Far East: Materials of the 5th Anniversary Scientific. Conf. "Towards the World Water and Meteorology Days", Vladivostok, 85-88.

Starozhilov, V. T. (2011). General Landscape Science and the Use of a Landscape Approach in Environmental Monitoring of Environmental Management: A Course of Lectures (p. 286). Vladivostok: Publishing House Dal'nevost.

Starozhilov, V. T. (2016). Landscape Geosystems of the Sakhalin Link of the Marginal-Continental Landscape Belt of Pacific Russia. Problems of Regional Ecology, 5, 53-57.

Starozhilov, V. T. (2017). The Concept of Areal Landscape Indication in the Policy of the Pacific International Landscape Center SHEN FEFU. Modern View of the Future of Science: Priority Areas and Development Tools: Collection of Articles. Scientific Art. on the Basis of the Intern. Scientific-Practical Conf., Kult Inform Press Publishing House, 37-39.

Starozhilov, V. T. (2018). Nature Management: Practical Landscape Geography: Textbook (p. 276). Vladivostok: Publishing House Dal'nevost.

Starozhilov, V. T., \& Oznobikhin, V. I. (2015). Landscape Geosystems of Russian Island Primorsky Krai [Electronic Resource]. Modern Research in the Natural Sciences: Materials of the II International. Scientific Conf. 26-28 Aug. 2015 Vladivostok (pp. 32-35). Vladivostok: Publishing House Dal'nevost.

Starozhilov, V. T., \& Zonov, Yu. B. (2009a). Study of Landscapes of Primorsky Krai for the Purposes of Nature Management. Geography and Natural Resources, 2, 94-100.

Starozhilov, V. T., Derbentseva, A. M., \& Nazarkina, A. V. (2012). Soils and Man-Made Surface Formations in Urban Landscapes. Vladivostok: Ministry of Education and Science of the Russian Federation, Far Eastern Federal University, University of Biology and Soil Science, Pacific State University.

Starozhilov, V. T., Evseev, A. B., \& Tkachenko, V. I. (2009c). The Processes of Mechanical Soil Degradation in Landscapes of Primorye: Monograph (p. 88). Vladivostok: Publishing House Dal'nevost.

Starozhilov, V. T., Krupskaya, L. T., \& Grehnev, N. I. (2009b). Ensuring the Environmental Safety of Environmental Risk Sources at Tin-Ore Enterprises in the South of the Far East. Vestn. RUDN Ser. "Ecology and Life Safety", 4, 81-88.

Starozhilov, V. T., Leonenko, A. V., \& Krupskaya, L. T. (2009d). Geoecology of the Mineral Resource use of Landscapes in the South of the Far East. Vladivostok: Ministry of Education and Science of the Russian Federation, Federal Agency for Education, Far Eastern Branch of the Russian Academy of Sciences, Institute of Mining, Far Eastern Federal University.

Starozhilov, V. T., Oznobikhin, V. I., Dedeva, A. A., \& Kudryavtsev, A. A. (2018). Landscape Map of Tracts and Tracts of Russian Islandand Adjacent Islands of the Vladivostok Urban District of 1:25000 Scale. Vladivostok: Dalnevostozh Publishing House. 